\title{
Students' Motivation and Expectation in Joining English Education Department at IAIN Kudus
}

\author{
${ }^{1}$ Suciati, ${ }^{2}$ Nurul Aini Rizqina, ${ }^{3}$ Annas Mukhlisuddin \\ Institut Agama Islam Negeri Kudus, Kudus Indonesia \\ (suci@iainkudus.ac.id)
}

Article History: Submitted December $26^{\text {th }}, 2019$; Accepted January $14^{\text {th }}, 2020$; Published March $13^{\text {th }}, 2020$

\begin{abstract}
English Education Department at IAIN Kudus is new study program. Nevertheless, the number of the students is always increased every year. This study aims to get information related to the educational background of students, analyze their motivation and expectation in joining English Education Department IAIN Kudus and analyze their ways in realizing the expectations. This study was descriptive qualitative research. It was conducted at English Education Department, IAIN Kudus. The subjects were 204 students from the first to third academic year. Data were collected through questionnaire, interview and document analysis. The results showed that $20,6 \%$ are boys and $79,4 \%$ are girls. $44,6 \%$ of the students graduated from science program, $26 \%$ from social program, 12,3\% from language program and the rest were from religion, computer and network engineering, sharia banking, accountancy and administration. They take and study English because of internal and external motivation. The internal factors are needs, plan, pleasure and meaning. And the external factors are learning environment, career, society and others. For the expectation, they expect to have class with clear curriculum, Students Centered Learning (SCL) and teaching media that meets their needs so they are able to develop English skills and be good English teacher/educator. And the students' ways in realizing their expectations are studying hard, critical thinking, using appropriate media and having partner.
\end{abstract}

Keywords: educational background, students' motivation and expectation, ways

Abstrak. Tadris Bahasa Inggris di IAIN Kudus adalah program studi baru. Namun, jumlah mahasiswa selalu bertambah setiap tahun. Penelitian ini bertujuan untuk mendapatkan informasi terkait latar belakang pendidikan siswa, menganalisis motivasi dan harapan mereka untuk bergabung dengan Tadris Bahasa Inggris IAIN Kudus dan menganalisis cara mereka dalam mewujudkan harapan mereka. Penelitian ini adalah penelitian deskriptif kualitatif di Tadris Pendidikan Bahasa Inggris IAIN Kudus. Responden sejumlah 204 mahasiswa dari tahun akademik pertama hingga ketiga. Data dikumpulkan melalui kuesioner, wawancara, dan analisis dokumen. Hasil penelitian menunjukkan bahwa 20,6\% adalah laki-laki dan 79,4\% adalah perempuan. 44, 6\% dari mereka lulus dari program sains, 26\% dari program sosial, 12,3\% dari program bahasa dan sisanya dari agama, teknik komputer dan jaringan, perbankan syariah, akuntansi dan administrasi. Mereka kuliah di TBI IAIN Kudus karena adanya motivasi internal dan eksternal. Faktor internal adalah kebutuhan, rencana, minat dan makna. Dan faktor eksternal adalah lingkungan belajar, karier, masyarakat dan lain-lain. Mereka berharap memiliki kurikulum yang jelas, Student Centered Learning (SCL) dan media pengajaran yang memenuhi kebutuhan mereka sehingga mereka dapat mengembangkan keterampilan bahasa Inggris dan menjadi guru / pendidik bahasa Inggris yang baik. Cara mahasiswa dalam mewujudkan harapan mereka adalah dengan belajar keras, berpikir kritis, menggunakan media yang tepat dan memiliki partner belajar.

Kata kunci: latar belakang pendidikan, motivasi dan harapan siswa, cara 


\section{INTRODUCTION}

English is always studied by many people in the world. This language still become the favorite for people around the world because by using this language, they can communicate; find the easy things even become successful. This international language must be mastered by all people, especially in this era where the government encourages the citizens to update everything because the development of science and technology is great. So, it can be said that by English, people can hold the world.

On the other hand, if we see the condition of education in this country, there are so many teachers who do not get the appropriate welfare and the job vacancy for this position is limited. Many graduates of English Education Department from various universities or colleges work not accordance in their educational background, difficult to find job, even jobless. This condition is very ironic. Nevertheless, the number of students who register in English Education Department is higher and higher. It can also be found in Institut Agama Islam Negeri (IAIN) Kudus. There are so many students who register in this study program although it is categorized as new study program at IAIN Kudus. From this condition, the researcher was so curious about the students' motivation and expectation. For that reason, she conducted the research entitled "Students' Motivation and Expectation in Joining English Education Department at IAIN Kudus".

The objectives of the research were to get the information related to the educational background of English Education Department students at IAIN Kudus; to know the students' motivations in joining English Education Department IAIN Kudus; to analyze the students' expectations in joining English Education Department IAIN Kudus; and to find the information related to the ways of English Education Department students at IAIN Kudus in realizing their expectations.

\section{METHOD}

In conducting the research, a researcher should use economical principle, whether it is time, energy, or is cost. As a process of finding out the empiric result, research has some steps or stages to do the process based on the fact. Some linguists have different definitions about research, but the point is same. Such Blaxter et al. (2001: 9) said that research is often presented as a fixed linear series of stages with a clear beginning and ending. Moreover, Cooper and Emong in Supranto (2003: 23) explained that research is a systematic inquiry with the purpose to provide the information and to solve the problem.

In this study, the researcher used descriptive qualitative study. Lamber and Lamber (2012: 255) explained that descriptive qualitative study has little "theoretical" if it is compared with other qualitative approaches. It tends to describe the naturalistic inquiry and takes the commitment to study something in its natural state fully so that it is possible within the context of the research arena.

This research was conducted at IAIN Kudus, especially focusing on the students of English Education Department. The number of respondents was 204 students. For getting the data, the researcher collected the data using two techniques. They were interview and document analysis. Bungin (2003: 67) explained that the researcher will be able to get the data if he does the deep interview. Based on this interview definition, the researcher could find the data related to the past, present, even in the future or plans of the new English Education 
Department students. The researcher did interview to the participants of the research deeply related to some points formulated in statements of the problem. They were the English Education Department students' educational background, motivation and expectation studying English in English Education Department study program at IAIN Kudus and their ways in realizing their expectation.

There were some supporting documents used to get the data of this research. The kinds of the documents were data related to the numbers, sex, and educational background of the new English students. This supporting data supported the main data.

\section{RESULTS AND DISCUSSION}

STAIN Kudus (now IAIN Kudus) was established on March 21, 1997, with the opening of three study programs, namely: Islamic Religious Education Study Program (PAI), Ahwal Syahshiyah (US), and Tafsir Hadith (TS). The development of study programs until 2017 reached 28 study programs. One of them is the English Education depart or Tadris Bahasa Inggris (TBI) and the curriculum refers to the vision of IAIN Kudus, namely Transformative Islam Development. Therefore, TBI has a vision, mission and goals that are in line with the institution's vision and goals.

TBI was established in 2016 to establish itself as an educational workforce educational institution (LPTK) which focuses on preparing experts and skilled as English teachers, with specificity as educators who have various special skills as stated in the curriculum structure of the TBI. The curriculum of the English Tadris Study Program (TBI) also pays attention to the potential and ability of IAIN Kudus and local wisdom. For example, the specifications possessed by educators, the socio-cultural of Pantura Central Java, especially Kudus as santri city.

TBI IAIN Kudus has formally started to open the students' registration since 2017. The vision of Tadris Bahasa Inggris is being great in the field of English education with a transformative Islamic outlook. Meanwhile, the missions of Tadris Bahasa Inggris IAIN Kudus are:

1. Organizing education and learning to produce professional English language educators, translators and journalists.

2. Organizing studies and research for scientific development in the field of English education.

3. Carrying out community service in the field of English education.

4. Establishing cooperation with various parties for the development of the organization of education in the field of English.

There are some objectives of Tadris Bahasa Inggris IAIN Kudus. They are:

1. Producing professional English language educators, translators and journalists.

2. Producing quality research and scientific work in the field of English language education.

3. Producing works and community service programs in the field of English language education.

4. Generating cooperation for scientific development and the organization of English education. 
Based on the conducted research, there were 204 respondents who participated in this research. They were the students of English Education Department of Tadris Bahasa Ingris (TBI) IAIN Kudus. From 204 respondents, 20,6\% of them are boys and 79,4\% are girls. They graduated from different major or program. From the result, 44, $6 \%$ of the students graduated from science program, $26 \%$ from social program and 12,3\% from language program. Meanwhile, the rest were from religion, computer and network engineering, sharia banking, accountancy and administration program. For the motivation why they choose study at TBI IAIN Kudus, some students had big willingness to study there. It means that this expectation is from themselves. And some of them were also supported and asked by their parents to take TBI IAIN Kudus. Moreover, other external factors also support them. Related to the students expectation for the success in learning, they expect to have clear curriculum, appropriate learning strategy and supporting media.

For the detail information, it will be discussed below.

\section{The educational backgrounds of English Education Department students}

The educational backgrounds of English Education Department students at IAIN Kudus are $44.6 \%$ of the students graduated from science program, $26 \%$ from social program, 12.3 $\%$ from language program and the rest were from religion, computer and network engineering, sharia banking, accountancy and administration. Their percentage is $20.6 \%$ are boys and $79.4 \%$ are girls. From this data, it can be known that the number of the girls dominate the number of boys.

Among 204 respondents, 23\% are from the academic year 2017, 37.3\% are from the academic year 2018 and $39.7 \%$ from 2019. And for the class category, 42.2\% students study in class A. $33.8 \%$ students study in class B and $24 \%$ in class C. For the establishment of the class, there was no certain requirement or regulations from campus. They are in different classes just based on their registration numbers. It is done by campus not to differentiate them.

\section{The students' motivations in joining English Education Department IAIN Kudus}

Based on the research, the students' motivation in learning English are classified as internal and external motivation. The internal factors are needs, plan, pleasure and meaning. And the external factors are learning environment, career, society and others. It happened in TBI IAIN Kudus.

Many students majored in TBI Tarbiyah Faculty IAIN Kudus because they wanted to focus on the language or English itself. In fact, if they want to be more careful in seeing the majors they take, TBI does not only focus on a handful of language studies but learns more about language teaching where TBI students are carefully prepared to enter the workforce to become teachers later after they finish taking at least undergraduate education.

Education major provides specific learning about languages but it differs in the level of depth and depend on the students' interests. If they care about the world of education, then there is no harm for them majoring in this department. In addition, they are not only taught about education but also are taught additional competencies to work in other fields (besides teacher training) which are still closely related to the use of English as an international language such as Journalism, Cross Culture Understanding, etc. 
English is an international language where the world of commerce (E-commerce) and technology (science and technology) has been highly controlled by this language. So, for being graduates who are capable in English and religion or Islam, many students chose IAIN or State Institute on Islamic Studies. By studying at IAIN Kudus, they wanted to get the knowledge and the religion or Islamic values.

Although TBI IAIN Kudus is new study program, they are not afraid if they study in a low accredited department. Many students stated that the point is they study seriously. They believe that if they study well, they will get the job well. They do not want to think more about the effect of the accreditation to their chance to get job. With low accreditation, people will be increasingly competing to advance infrastructure, productivity and quality of graduates. It is useless if they go to a high accreditation department but they have no interest in entering that department. It is better to study in a low-accredited department but the department is according to their passion. Not depend on accreditation, but it depends on how they can improve the quality of themselves as students. Nevertheless, they have big expectation so that TBI IAIN Kudus will get the best accreditation. They have supported it by joining the competitions and organizations so they want to improve the quality of their department.

Moreover, they took TBI IAIN Kudus because of the economical price. If they study in the private campus, the price will be so expensive. So that why, they finally tried to find the state campus that has reachable price. From 204 respondents, there were 89,2\% students who chose TBI IAIN Kudus as the first choice. 10.3\% students chose it as the second choice. And the rest are as the third choice.

Based on the interview, there are internal and external factors influencing the students' motivation to study at TBI IAIN Kudus. The internal factors are needs, plan, pleasure and meaning. And the external factors are learning environment, career, society and others.

In this revolution industry 4.0 era, there will be more developments in this country. Starting from free trade, more and more foreign companies stand in Indonesia so that the use of international languages such as English has been very widespread, of course for prospective entrepreneurs and job seekers has become a necessity to be able to master English in order to face this era. It is understood well by the students so they took English department. Along with the development of the world, the era is increasingly influential in all aspects of life such as technology, transportation, education, and others. Therefore, the ability to be able to speak English is increasingly important and needed because the free market continues in progress. For that reason, the students do realize that this condition increasingly interacts with strangers or are up to date with foreign news.

If they do not master English, their knowledge will certainly be limited because English is a universal language. For example, many international books or seminars are delivered in English because they are representative of all languages in the world. Moreover, the young generations cannot be separated from social media, applications, gadgets or technology development. As social beings, it is certain that in their daily lives, they communicate and interact with their friends, not just in regional or national scope, but also international scope. For that reason, they do really enjoy studying English. 


\section{The students' expectations in joining English Education Department IAIN Kudus}

Based on the analysis, the students expect to have class with clear curriculum, Students Centered Learning (SCL) and teaching media that meets their needs so they are able to develop English skills and be good English teacher/educator.

For the profession, there are some expectations from the students. Those professions are:

1. English teacher

The profession as a teacher is very closely related to the department they take in campus, namely English Education. This study program focuses its students to have expertise in the field of education, as well as providing knowledge to their graduates to engage in teaching and learning activities.

This department also provides a certificate in the form of Akta IV which is a special requirement for graduates of English education to become teachers. Teacher is a noble profession because the teacher provides knowledge and teaches good role models for their students.

With this English Education major, they can continue their profession to a higher level, which is to become an English Language Lecturer. With S2 or S3 education qualifications, they will get a different professional experience as a teacher beforehand. By becoming a Lecturer, there are some mandatory tasks that they must carry out, for example research and community service. They must be consistent in conducting research and taking an active role in community activities. So, no need to worry about the profession that they will live later; becoming a teacher or lecturer is the main choice after they have a degree in English Education. Nevertheless, if they cannot be a teacher or lecturer, there are some professions that they want to reach. They are like translator, tour guide and author.

\section{Translator}

This profession is needed by people who are working in the world of work with various fields of expertise. For example, the field of law, economics, or the field of tourism. People or companies in these fields need translator services to translate documents, letters, journals, or training material in a company or government agency.

Because they are an English Education graduate, the focus of the translation includes translating English into Indonesian, or vice versa. Many people, companies, or agencies that require this service, because they do collaborations or get partners who come from abroad, especially English-speaking countries. So, the students do not hesitate to become a translator because they will get new things and will certainly improve their English vocabulary from various fields of science.

\section{Employee/staff}

English is a skill that must be possessed by everyone. If the person has English language skills, of course it will be easy to get a job and will have added value for the agency or company that is recruiting employees. It will be a good consideration for them because 
they have more expertise in foreign languages, namely English. This certainly can be beneficial for them.

With English skills which may have become soft skills, it will certainly make it easier for to compete in the world of work. With these abilities, they will be well considered and compared to employees or job seekers who do not have English language skills. Being an employee in a foreign department will be a job that might be a great opportunity for them. Or they can get the opportunity to work in institutions or companies with international standard because conversations using English will become a daily necessity in the workplace.

\section{Tour Guide}

From the positive side, being a tour guide has a lot of experience and benefits. When they become a tour guide, they are required to be able to speak English properly and correctly. They states that they will listen and say something in English, so their ability to speak and listen English is getting better and better. This one thing must be felt by all tour guides. Everywhere they will not be silent on the road. They only armed with knowledge of tourist attractions to be addressed and their English language skills. They feel the tour guide is not a job but a free walk with a handsome and beautiful tourist.

They said that being a tour guide is fun, especially if they become a tour guide for tourists who are handsome and beautiful. As a tour guide, they get the opportunity to get acquainted, share contacts such as social accounts. In fact, not infrequently some tour guides have become a couple of tourists and they are invited to live in the country of origin of the tourist. Being a tour guide will make them more independent because they are a guide as well as leading. Like when there is a problem, whether it is an administrative problem, tourists who complain about something are required to find a way out.

\section{Author}

If the students cannot become a teacher, some of them want to be a writer or author. By writing, they can express what they want to say. Indirectly, they also can teach and transfer their kowledge to the other people. They are the readers.

To reach their dreams, they have some expectations in joining English Education Department at IAIN Kudus. Although TBI is new study program but they hope that this program can have clear curriculum like what the government set. It is KKNI or Kerangka Kualifikasi Nasional Indonesia curriculum for campus. In the teaching and learning process, the students of TBI also have big expectation to the lecturers, especially their teaching model. Because studying English involves the skills so they take a priority to practice. For that reason, the students prefer having Students Centered Learning (SCL) than Teacher Centered Learning (TCL) and teaching media that meets their needs so they are able to develop English skills and be good English teacher/educator. 


\section{The ways of English Education Department Students at IAIN Kudus in realizing their expectations}

Based on the analysis, there are some ways of students to realize their expectations. They are by:

\section{Having Critical Thinking}

Critical thinking for the students of TBI IAIN Kudus is the ability to think clearly and rationally about what they want to do or what they believe. It includes the ability to engage in reflective and independent thinking. By having chritical thinking, they hope to be able to:
a. understand the logical relations among the ideas
b. identify, construct and evaluate the idea or arguments
c. detect inconsistencey and mistakes in delivering the reasons
d. solve the problems systematically
e. identify the relevance and importance of ideas
f. reflect on the justification of one's own beliefs and values

Critical thinking is not just accumulating information. A person whose good memory and who knows a lot of facts is not always good at critical thinking. A critical thinker is able to deduce consequences from what he knows, and he understands how to make the information to solve problems, and to seek relevant sources of information to add their knowledge.

Critical thinking should not be confused with being argumentative or being critical of other people. Although critical thinking skills can be used to expose fallacies and bad reasoning, it can also play an important role in cooperative reasoning and constructive tasks. Critical thinking can help the students acquire knowledge, improve their theories, and strengthen their arguments. They can use critical thinking to enhance work processes and improve social relations.

Some people believe that critical thinking hinders creativity because it requires the rules of logic and rationality, but creativity might require breaking rules. This is a misconception. Critical thinking is quite compatible with thinking "out-of-the-box", challenging consensus and pursuing less popular approaches. If anything, critical thinking is an essential part of creativity because they need critical thinking to evaluate and improve their creative ideas.

In this context, the students said that critical thinking is not always related to the intelligence quotient, but nowadays, they also must be critical in selecting the relations or values. Because they study in Islamic institution, they expect that they are always able to implement the Islamic values and character education in their lives. 


\section{Using Appropriate Media/Social Media}

In realizing the expectation, the students use the media because of various advantages. Media means media that they or their lecturers use in the classroom or social media that they can use to support their study.

Basically, social media (Facebook, Twitter, Whatsapp, YouTube, Instagram, etc.) aims to establish communication with various purposes, for example, as a promotional event, find friends, discuss media, share things and other social things. In this case, social media should be able to be used to support student studies, such as finding information related to college assignments, class schedules, sharing various matters of education, etc. For having communication and getting information, they make whatsapp group for their class and organizations.

\section{Having partner}

They have various background and skills. For that reason, having partner for studying English is very important for them. For example, by having partner to speak English, it will help them more to abe able to speak English fluently. The benefits of having a study partner for the students of TBI are:

a. A study partner will help students remember deadline or the date of an exam. By sharing the agenda, study partner and both of students will know when a big project or paper is due.

b. A study partner can test each other before having a test. It is like test simulation.

c. Two heads are better than one, so the study partner may think of practice essay questions that another does not think of.

d. A study partner will understand some methods or problems that another does not. Students will be able to explain some of the problems to another partner in return.

e. Study partner may be able to help another friend about the material.

f. Students can get benefit from sharing the strengths. One may be better with grammar, while the other is better in speaking. So they can complete each other.

g. Study partner can motivate each other and reduce the potential for procrastination.

h. Study partners can be there if students forget important tools--like a calculator, dictionary or notebook paper.

\section{CONCLUSION}

Based on the analysis, there are some conclusions. The first; the educational backgrounds of English Education Department students at IAIN Kudus are 44, 6\% of the students graduated from science program, $26 \%$ from social program, 12,3\% from language program and the rest were from religion, computer and network engineering, sharia banking, accountancy and administration. Their percentage is $20,6 \%$ are boys and $79,4 \%$ are girls. Second, The students' motivations in joining English Education Department IAIN Kudus Learning English are internal and external motivation. The internal factors are 
needs, plan, pleasure and meaning. And the external factors are learning environment, career, society and others. Third; The students' expectations in joining English Education Department IAIN Kudus are to have class with clear curriculum, Students Centered Learning (SCL) and teaching media that meets their needs so they are able to develop English skills and be good English teacher/educator. And the fourth; The ways of English Education Department students at IAIN Kudus in realizing their expectations are by studying hard, having critical thinking, using appropriate media/social media and having partner

\section{REFERENCES}

Al Othman, M. and Shuqair, KM. (2013). The Impact of Motivation on English Language Learning in the Gulf States. International Journal of Higher Education Vol. 2 No. 4. Available online at https://files.eric.ed.gov/fulltext/EJ1067550.pdf. Accessed on 5 October 2017.

Blaxter, et al. (2001). How to Research. Maidenhead: Open University Press.

Bungin. (2003). Analisis Data Penelitian Kuantitatif. Jakarta: Rajawali Press.

Celce-Murcia, M. (2001). Teaching English as a Second or Foreign Language,. United State of America: Inc. Thomson Learning,

Hasan, DC. (2018). What Factors Influence Changes in Students' Motivation to Learn English as a Foreign Language?. Available online at https://www.asian-efljournal.com/wp-content/uploads/AEFLJ-Quarterly-Volume-20-Issue-2-2018.pdf. Accessed on September 14th 2018.

Jin, L., et al. (2014). Motivations and Expectations of English Language Learning among Primary School Children and Parents in China. ELT Research Papers 14.01. British Council. Available online at https://www.teachingenglish.org.uk/sites/teacheng/ files/E202\%20MEEL\%20-\%20ELTRA\%20FINAL\%20v2.pdf. Accessed on September 14th 2018.

Lamber, V.A and Lamber, C.E. (2012). Qualitative Descriptive Research: An Acceptable Design. Pacific Rim International Journal of Nursing Research, October-December Edition. Available online at https://www.tci-thaijo.org/index.php/PRIJNR/article /download/5805/5064. Accessed on 5 October 2017.

Leask, B. and Carroll, J. (2013). A Quick Guide to Developing English Language Skills. IEAA.

Souriyawongsa, T., Ismail Raob and Mohamad Jafre Zainol Abidin. (2012). Study on Students' Motivation in Joining An English Course. Journal of Education and Learning. Vol.6 No. 3. Available online at http://journal.uad.ac.id/index.php/EduLearn/article/download/157/pdf. Accessed on September 14th 2018.

Supranto. (2003). Metode Penelitian Hukum Statistik. Jakarta: Rineka Cipta. 
Thabet, AMA. (2012). The Reasons for Joining the English Department. International Journal of Education Vol. 4, No. 4. Available online at https://www.researchgate.net/publication/316158604_The_Reasons_for_Joining_th e_English_Department. Accessed on September 302019. 